\title{
MOSQUE MANAGEMENT RESPONSE TO PRODUCTIVE WAQF
}

\section{Suhairi}

State Islamic Institute Metro

Iring Mulyo, East Metro, Metro, Lampung, Indonesia, 34112

E-mail:suhairi@metrouniv.ac.id

\begin{tabular}{c|c|c}
\hline Received: & Revised: & Approved: \\
$03 / 08 / 2019$ & $02 / 09 / 2019$ & $08 / 10 / 2019$ \\
\hline
\end{tabular}

DOI: https:// doi.org/10.32332/akademika.v24i2.1818

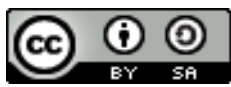

Mosque Management Response To Productive Waqf Licensed Under a Creative Commons Attribution-ShareAlike 4.0 International License

\begin{abstract}
Questions in this study are: What is the response of the board to the management of mosque-based productive waqf? The purpose of this study is to elaborate the management's response to the management of productive mosque-based waqf. The research conducted wasfield research, in the form of a mosque that met the criteria used as a research location. Mosque criteria are those that have the potential of managing a mosquebased productive waqf. Data collection is done through interviews. From the four mosques studied, the management's response had differences. The response of the mosque management and or the foundation, one mosque, the Babussalam Pekalongan East Lampung Mosque, the management objected if it was built in the front yard of the shop. The reason stated, the existence of the mosque for worship, not for business. While the management of the other three mosques agreed and strongly agreed that a mosque-based productive waqf management would be carried out by building shops in its front yard.
\end{abstract}

Keywords: Productive Waqf, Nazhir, and Empowerment of Waqf Land

\section{A. Introduction}

Law Number 41 of 2004 carries the paradigm of productive endowments. The potential of waqf land is very much, has not been 
managed optimally. There are still many waqf lands that have not been managed productively. The function of waqf in Act Number 41 of 2004 concerning Waqf states that waqf lands are realized with the potential and economic benefits of waqf assets. ${ }^{1}$ Given waqf is an economic instrument. ${ }^{2}$ To realize this endowment lands must be managed productively. ${ }^{3}$ Included in this case are mosque waqf lands which have the potential to be managed productively. The area of land used for building mosques turned out not to use all of the land. The mosque's vacant land can be utilized as a mosquebased productive waqf model.

Several potential mosques were found to be managed as productive mosque-based endowments. Potential for a number of mosques that have the prospect of being managed productively with the criteria there are still remaining land outside the mosque building and strategic location. The strategic location is on a fairly busy street, especially if it is near the market. Based on these criteria, several mosques have been identified that have the potential and prospects to be managed productively. Based on this, it is interesting to study and study the prospects for managing mosque-based productive waqf. The mosques are the Babussalam Pekalongan Mosque and the East Lampung Jami 'Batanghari Mosque, the Central Lampung Taqwa Mosque, and the al-Muhajirin Semuli Jaya Mosque in North Lampung.

In connection with the realization of productive management of waqf based on mosques, it is highly dependent on the commitment of mosque administrators as Nazaf waqf. Commitment depends greatly on the response of the mosque management to the management of productive mosque-based waqf. Based on this, then the problem can be formulated: How do the management response to the management of mosque-based productive waqf? To find out the management response to mosque-based productive waqf management. So that it is expected to be able to open up insight into the potential mosque management and the realization of productive mosque-based waqf management.

\section{B. Productive Waqf}

Based on aspects of its use, endowments are divided into two types, namely direct (consumptive) endowments and indirect endowments

1 “Undang-Undang Nomor 41 Tahun 2004 Tentang Wakaf" (T.T.).

2 Amir Mu'allim, "Pengaruh Pengelolaan Wakaf Di Mesir Terhadap Pengelolaan Harta Wakaf Pendidikan Di Indonesia," Jurnak Akademika 20, No. 01 (2015): 119.

3 Akhmad Sirojudin Munir, "Optimalisasi Pemberdayaan Wakaf Secara Produktif," Jurnal Ummul Qura Vi, No. 2 (September 2015): 95. 
(productive endowments). Consumptive Waqf is also called direct waqf because the waqf object feels its benefits directly by the beneficiary. While productive waqf is called indirect waqf because the object of waqf is not directly felt by the beneficiaries. However, the waqf property is productive first and the results are distributed to the waqf beneficiaries. In this case, the benefit of the endowment is not immediately felt by the beneficiary of the endowment (maukuf alayhi), but it is productive, and the results are distributed to the endowment beneficiaries. ${ }^{4}$ Productive endowments are thus the development of old interpretations of endowments. ${ }^{5}$ Productive waqf managers are required to work more professionally than consumptive waqf managers. This happens because productive waqf managers must be able to explore and realize the economic potential of waqf property. The ability of investment management is needed in managing productive waqf. According to Syafii Antonio, there are three things in the character of professional waqf management: (1). The management used is management in the "integrated project" frame. (2). The principle of welfare Nazir. Management of productive waqf is demanded professionally, so that the welfare of the Nazari need to be considered, so that Nazaf can manage productive waqf optimally. (3) The principle of transparency and accountability. Management of productive waqf that definitely generates income, must be managed openly and can be accounted for. Reports on productive waqf management are submitted regularly and can be accessed by anyone ${ }^{6}$

Talking about productive waqf management, it is synonymous with efforts to realize the economic improvement of the people. ${ }^{7}$ Waqf has become an economic instrument. ${ }^{8}$ Economic improvement can be done

4 Suhairi, "Implementasi Fungsi-Fungsi Manajemen Dalam Pengelolaan Wakaf Produktif Di Singapura," Jurnal Akademika, 20, No. 01 (Juni 2015): 125.

${ }^{5}$ Muhyar Fanani, Berwakaf Tak Harus Kaya: Dinamika Pengelolaan Wakaf Uang Di Indonesia (Walisongo Press, 2010).

6 Syafii Antonio, "Pengantar Pengelolaan Wakaf Secara Produktif, Dalam Buku Yang Ditulis Oleh Achmad Djunaidi Dan Thabib Al-Asyhar," Dalam Menuju Era Wakaf Produktif: Sebuah Upaya Progresif Untuk Kesejahteraan Umat (Jakarta: Mitra Abadi Press, 2006), Vii-Viii.

7 Direktorat Pemberdayaan Wakaf Dirjend Bimbingan Masyarakat Islam Departemen Agama, Model Pengembangan Wakaf Produktif (Jakarta: Deoartemen Agama Ri., 2008).

8 Anwar Pitchaya, Ahamed Kameel Mydin Meerab, Muhammad Yusuf Saleemc, "Priority Of Waqf Development Among Malaysian Cash Waqf Donors: An Ahp Approach," Iium Institute Of Islamic Banking And Finance, Journal Of Islamic Finance, 3, No. 1 (2014): 14. 
through empowering waqf. 9 Strategic productive waqf lands can be maximally empowered in the form of: 10

a. Waqf assets that produce goods and services

Waqf assets are managed or productive in forms of business that can generate profits, in the form of goods or services.

b. Waqf assets in the form of business investment

These waqf assets are managed or produced through investments in third parties or other institutions. Considering that the managed assets are waqf assets, they must meet sharia standards, namely: musyarakah and mudharabah contracts and other contracts in accordance with sharia principles.

\section{Research Methods The}

research conducted isfield research, in the form of research to explore the mosque management's response to productive endowments. Some mosques that have been observed and meet the criteria are used as research locations. The criteria in question is, mosques that have adequate courtyards and are strategically located, namely on the side of the road and or near markets or centers. Several mosques that have been identified and selected, namely: Babussalam Mosque in East Lampung Pekalongan, Jami 'Batanghari Mosque in East Lampung, Taqwa Mosque in Central Lampung, al-Muhajirin Abung Semuli Mosque in North Lampung. Based on the mosques that have been chosen, this potential will be explored, in the form of the possibility to be developed and managed productively and the response of the mosque's management.

Data collection in this study was conducted by interview. Interviews were conducted with the management of the mosque / foundation to explore the data of the management's response to productive endowments. The response of the mosque management / foundation in the form of an opinion agree or disagree, the reasons and the possibility of realizing productive waqf management in the yard of the mosques.

Exposure and data analysis were carried out to discuss and answer research questions. The analysis was carried out in a descriptive qualitative manner, with the method of inductive thinking.

${ }^{9}$ Nursyifa Yolanda, "Peranan Wakaf Produktif Terhadap Keberlangsungan Usaha Mikro Kecil Menengah (Umkm) Dan Kesinambungan Badan Wakaf Walisongo," T.T., 11.

10 Panduan Pemberdayaan Tanah Wakaf Produktif Strategis Di Indonesia, T.T., 1036. 


\section{Response of Mosque / Foundation Managers to the Management of Productive Waqf-Based Mosques}

1. Jami 'Batanghari Mosque Jami' Batanghari

Mosque is located in Banar Joyo village, Batanghari sub-district, East Lampung regency. The Jami 'Batanghari Mosque stands on a waqf land of $1500 \mathrm{~m}^{2}$, while the main building area of the mosque is $100 \mathrm{~m}^{2}$, including a terrace of $143 \mathrm{~m}^{2}$. The Jami 'Batanghari Mosque stands on land represented by Mr. Budiono in 1987.11

The location of the Jami' Batanghari mosque is east and south bordering the market road, the north is bordered by irrigation channels, the west is bordered by the Office of Religious Affairs (KUA) ) Batanghari. Across the road to the east and south stand Batanghari market shops. Based on this condition, it can be said that the Jami 'Batanghari mosque is located in the Batanghari market area / location.

The researcher asked and at the same time explored the opinions and thoughts of the mosque head, did he agree if the mosque yard was built by a shop for productive empowerment of waqf land? He conveyed, during the management of the mosque which was chaired by Mr. Budiono, about 15 years ago, he had raised ideas / thoughts about the productive use of waqf land. But the idea, as far as Mr. Karsoyo is concerned, more people / mosque worshipers did not approve of it. So that thoughts / ideas never reappear. In connection with the re-emergence of the thought of productive waqf land management in the Jami 'Batanghari mosque, he expressly agreed. To realize this, according to him, careful planning needs to be discussed with the mosque management. ${ }^{12}$

Regarding mosque-based productive waqf management, Mr. Karyoso as Chairperson of the Jami Mosque 'Batanghari expressly agreed, if in the courtyard of the Jami mosque' that is still large enough to be built in shops / mini markets and so on for productive waqf management. In this case, he said that the mosque has income to finance mosque activities, other religious activities, including for mosque needs and mosque renovation. As well as empowering and developing the surrounding community's economy. ${ }^{13}$

Likewise, the Imam Imam Syafi'i, as the Trustee in the management of the mosque, said that he agreed with the idea of building a shop / mini market / Baitul Maal wa Tamwil and so on in the courtyard of the mosque. As stated by the Chairperson, according to him, priority needs to be made,

\footnotetext{
${ }^{11}$ Karyoso, Wawancara Dengan Ketua Masjid Jami’ Batanghari, 4 Juli 2018.

12 Karyoso.

${ }^{13}$ Karyoso.
} 
whether to renovate the mosque first, or prioritize building shops in the mosque courtyard. ${ }^{14}$

Based on the committee's response, it can be stated that they agreed that there was an effort to create a mosque-based productive waqf. In connection with the social organization that was followed by the Chairperson of the Mosque, namely Pak Karyoso, the other was Nahdhatul Ulama. Pak Karyoso as the head of the Ma'arif school, which is an NU school, stated firmly in agreement with the management of the mosquebased productive waqf. So as to realize the productive management of waqf based on the mosque it is quite open, although according to the Chairperson of the Mosque, is currently planning the construction / renovation of the mosque. Related to this, the mosque management including those who agree to manage productive waqf based on the mosque, although including nahdiyin residents.

\section{Babussalam Mosque Pekalongan East Lampung}

Babussalam Mosque is located in Adirejo village, Pekalongan district, East Lampung district. Babussalam Mosque in East Lampung Pekalongan stands on waqf land covering an area of $1670 \mathrm{~m}^{2}$, while the area of the main building of the mosque is $225 \mathrm{~m}^{2}$, including a terrace of an area of $289 \mathrm{~m}^{2}$. The Babussalam Mosque stood on the land represented by Mr. Sudiono in $1982 .{ }^{15}$

The location of the Babussalam Pekalongan mosque in the north is bordered by the main road of Pekalongan, in the east it is bordered by the road to the residents 'villages which are bordered by a field, the west is bordered by residents' houses, the north is bordered by the main road of Pekalongan. the south borders the homes of residents. Around 200-300 m from the mosque to the east, there is a Pekalongan District office and Puskesmas, around $500-600 \mathrm{~m}$ from the mosque there is a Pekalongan market. About $100-200 \mathrm{~m}$ from the mosque to the west, there is the Pekalongan Police Station. Around the mosque, both east, south, west and north, are already fairly dense residential settlements ${ }^{16}$

After observing the condition of the area of the Babussalam Pekalongan mosque, and its very strategic location, the researchers concluded that the Babussalam mosque's land / yard could be

14 Imam Syafi'i, Wawancara Dengan Dewan Pembina Masjid Jami' Batanghari Lampung Timur, 4 Juli 2018.

15 Romi, Wawancara Dengan Ketua Masjid Babussalam Pekalongan Lampung Timur, 8 Juli 2018.

16 "Observasi Sekitar Masjid Babussalam Pekalongan Lampung Timur," 7 Juli 2018. 
productively empowered. Several types of businesses can be done, taking into account the location of the land / yard of the Babussalam Pekalongan mosque. Researchers interviewed the mosque's tamir secretary, Mr. Supri.

The mosque secretary said that the proposal / thought to build a shop in the mosque yard had been carried out, but the majority of worshipers and mosque administrators did not approve it. The majority of worshipers and caretakers of the mosque said, if the waqf land is intended for the mosque (worship), then enough and no need to build a shop and so on. ${ }^{17}$

Likewise, one of the other mosque management, said that the discourse of building a shop in the Babussalam mosque yard had already been proposed, but the majority of the management and worshipers disagreed with this. So that he also affirmed that he disagreed if it was built in the yard of a shop mosque. According to him, for shops and other business buildings, it is better in other places, not in the mosque courtyard. ${ }^{18}$

Based on this, the tendency of the Babussalam Pekalongan mosque congregation does not agree with the efforts in the mosque courtyard. Although there are those who disagree because of the need for parking space for mosque pilgrims. But there are those who state firmly that there is no need for business in the courtyard of the mosque. They have an opinion, enough mosque land is used for the mosque and its facilities, including parking lots.

\section{Taqwa Mosque, Central Lampung,}

Taqwa Mosque, hamlet 1 RT 02 RW 02, village / village, Tanggul Angin, Punggur sub-district, East Lampung regency. The Central Lampung Taqwa Mosque stands on waqf land covering an area of around 2,500 $\mathrm{m}^{2}$, while the area of the main mosque building is $300 \mathrm{~m}^{2}$, including a terrace of $324 \mathrm{~m}^{2}$. The Taqwa Mosque stands on land that is represented / donated from the assets of the Tanggul Angin village, there is an individual endowment namely parents Aziz, there is also a collective endowment. Waqf collectively here is, residents raise funds to buy land behind the mosque's land, then represented. ${ }^{19}$

The north of the Taqwa Punggur mosque is bordered by the main road (provincial road), the east is bordered by the main road and the opposite is

17 Supri, Wawancara Dengan Sekretaris Ta'mir Masjid Babussalam Pekalongan Lampung Timur, 9 Juli 2018.

18 Amat, Wawancara Dengan Pengurus Masjid Babussalam Pekalongan Lampung Timur, 9 Juli 2018.

19 Abdul Aziz, Wawancara Dengan Ketua Ta'mir Masjid Taqwa Punggur Lampung Tengah, Agustus 2018. 
the Punggur market, the west is bordered by shops 'houses, the south is bordered by residents' land / houses. About $100 \mathrm{~m}$ from the mosque to the east of the District Religious Affairs Office, around $200 \mathrm{~m}$ there is a District office and Punggur Health Center. Likewise there are also several schools near the mosque. ${ }^{20}$

With regard to the use of waqf land in the courtyard of the mosque, by building shops / mini markets and others, Mr. Asngari, as the deputy chairman of the mosque management, firmly agreed. The relevant reason for agreeing to this is to revive the economy of the people, also so that mosque funds can be productive. When asked, what if implemented in the courtyard of the Taqwa Punggur mosque, then he stated personally agreed, but for the approval of other management, it needed to be discussed and discussed with other management. ${ }^{21}$

Based on what Pak Asngari said, he agreed to use the waqf land for the mosque's yard to build a shop / mini market and so on. The reasons put forward to revive the economy of the people as well as that mosque funds can be productive. Meanwhile, if realized in the Taqwa Punggur mosque, it will be discussed and discussed in advance with other administrators. So in this case, the parties concerned agreed if it was held at the Taqwa Punggur mosque.

The results of the interview with Mr. Aziz, as the Chairperson of the Taqwa Punggur Mosque, said that he strongly agreed with the idea of building a shop in the front yard of the mosque. According to him such thoughts have been raised, but considering that he is currently focusing on building the Madrasah Ibtidaiyah building in the backyard of the mosque. He further said, if the Ibtidaiyah Madrasah building was completed, then the Madrasah Ibtidaiyah class building in the front yard of the mosque would be moved, so that the opportunity to build shops was even greater. ${ }^{22}$ The courtyard of the Taqwa mosque, both at the front (north side), as well as at the rear (south side), is very broad. So that the backyard of the Taqwa mosque is very possible to build the Madrasah Ibtidaiyah building and become one, no more in the front. So that the front yard of the mosque is very broad, can build shops in quite a number.

Based on the results of the interview, both Pak Aziz and Pak Asngari agreed to build shops in the front yard of the mosque. If the process of 2018.

20 "Observasi Sekitar Masjid Taqwa Punggur Lampung Tengah," Agustus

21 Asngari, Wawancara Dengan Wakil Ketua Masjid Taqwa Punggur Lampung Tengah, Agustus 2018.

22 Abdul Aziz, Wawancara Dengan Ketua Ta'mir Masjid Taqwa Punggur Lampung Tengah. 
constructing the Madrasah Ibtidaiyah building is finished, they are ready to discuss further the management of productive mosque-based waqf. In this case, the researcher said, it was necessary to have a focus group discussion with all management and the research team ready to assist and facilitate the steps that needed to be done.

Based on the mosque management's response to the management of mosque-based productive waqf, it can be stated that they agree on this. In connection with affiliation with Islamic social organizations, the head of the mosque's governor, Mr. Aziz, is a Nahdhiyin / Nahdhatul Ulama citizen. When questioned by Mr. Asngari in relation to affiliation with Islamic social organizations, the person concerned declared Nahdhiyin worship, but in certain respects it was different, including in terms of political choice. Noting these expressions, it can be stated, affiliation, the participation of a person as a member / member of certain Islamic community organizations, does not make the person concerned follow the overall policies of the organization.

\section{Al-Muhajirin Mosque Abung Semuli North Lampung}

Al-Muhajirin Mosque is in Semuli Jaya village, Abung Semuli subdistrict $^{23}$ North Lampung. Al-Muhajirin Mosque Abung Semuli North Lampung stands on waqf land covering an area of $10,000 \mathrm{~m}^{2}$, while the area of the main building of the mosque is $225 \mathrm{~m}^{2}$, including a terrace of $320 \mathrm{~m}^{2}$. The Al-Muhajirin mosque building is a donation from the Pancasila Muslim Charity Foundation. Al-Muhajirin Mosque stood on land represented by the Air Force in 1988.24 According to Mr. Nanang, this waqf land has been certified and registered as waqf land. ${ }^{25}$

The location of the Al-Muhajirin Abung Semuli mosque is very strategic, to the south is bordered by the main road-across from the subdistrict office, SMAN 1, SMPN 1, Muhamadiyah Vocational School, Semuli Jaya's old market, and densely populated settlements. The east side is bordered by the PGRI Vocational School, and about $100 \mathrm{~m}$ of the new Semuli Jaya market, POS Office and crowded residential areas. The west

23 "Sebelumnya Menyatu Dengan Kecamatan Abung Selatan, Kemudian Dilakukan Pemecahan, Sehingga Abung Semuli Menjadi Kecamatan Sendiri.," T.T.

24 "Desa Semuli Jaya, Semuli Raya Merupakan Pemukiman Tentara Nasional Indonesia (Tni) Angkatan Udara Republik Indonesia. Sehingga Tanah Yang Dibangun Di Atasnya Masjid Al-Muhajirin Merupakan Tanah Milik Auri Yang Telah Diwakafkan Untuk Masjid.," T.T.

25 Nanang Setiawan, Wawancara Dengan Sekretaris Yayasan Masjid AlMuhajirin Abung Semuli Lampung Utara, 9 September 2018. 
side is bordered by residents' houses, and the road, the north is bordered by residential areas. ${ }^{26}$

Masjid Al-Muhajirin Abung Semuli, North Lampung, the condition of the yard and the size of the land is almost the same as the Taqwa Punggur mosque. Al-Muhajirin Mosque even has more land area compared to the Taqwa mosque. Such conditions are very potential for a mosque-based productive waqf management. Likewise, the location is relatively strategic, which is on the side of the main road, near the market, sub-district office, and many surrounding schools, PT. POS, and residents are quite dense residents.

The results of an interview with Mr. Amad Jazuli, as Chairman of the Al-Muhajirin Mosque Foundation, that he strongly agreed with the thought of managing a mosque-based productive waqf. According to him, this thought had arisen in this way and had been discussed about 2 (two) years ago. In principle, both the mosque's management and the foundation's management approve the idea or thought. But that is still an obstacle in terms of capital. ${ }^{27}$

When asked the reason concerned agreed with the thought of managing a mosque-based productive waqf, then the reasons were conveyed, namely: the existence of the ummah's economy, could increase mosque cash (from store rent), automatically add mosque worshipers, the mosque's environment seemed more alive, reduce unemployment. ${ }^{28}$ Based on what was conveyed, the thought or reason of agreement concerned with the thought of managing a mosque-based productive waqf is very advanced. Various aspects can arise, both in terms of economic activity, reducing unemployment, to the prosperity of the mosque. If such thoughts are shared by all mosque and foundation management, then the AlMuhajirin mosque has the potential to be a productive mosque-based waqf management.

What's interesting is that when asked about affiliation or participation in Islamic ORMAS, the person concerned stated that he was a board of NU and also a Muhammadiyah executive. ${ }^{29}$ Based on this, it can be stated that those concerned are active in the management of Islamic ORMAS not based on religious understanding and amaliyah, but the organization is merely used as a medium or a forum for activities and services for the people.

26 "Observasi Sekitar Masjid Al-Muhajirin Abung Semuli Lampung Utara," 9 September 2018.

27 Ahmad Jazuli, Wawancara Dengan Ketua Yayasan Masjid Al-Muhajirin Abung Semuli Lampung Utara, 9 September 2018.

28 Ahmad Jazuli.

${ }^{29}$ Ahmad Jazuli. 
Likewise, when asked to Mr. Nanang, as the Secretary of the Foundation, whether he agreed if in the courtyard of the Al-Muhajirin mosque, shops were built for economic activities, then he was agreed to. In full he conveyed, for me personally and also as the administrator of the mosque, as long as it was approved by the foundation I agreed and supported. The reason is because in addition to being able to increase mosque income it also improves the economy around the mosque. Similar to what was conveyed by Mr. Jazuli, that the discourse had appeared and discussed, only there was no follow up. ${ }^{30}$ Almost the same thought as Pak Jazuli, the secretary of the Pak Nanang Foundation strongly supports the mosque-based productive waqf management.

While the results of an interview with Mr. Sandi, as the Chairperson of the Al-Muhajirin Mosque, he also firmly agreed that if a mosque building was built for economic activities in the courtyard of the mosque. The reason is, because he has a concept in the yard of the mosque will be built stalls for rent, with the terms and conditions set by the Mosque Management Council. Likewise, the mosque can prosper and the mosque's finances can also be independent. ${ }^{31}$ Getting answers and explanations like that, the researcher conveys, extraordinary thinking is concerned. We have the same vision, the researchers assert that they are ready to discuss, participate in realizing this. Capital problems researchers say can share thoughts. Hopefully we can arrange a focus group discussion (FGD) with other management, including village officials and other stakeholders. In this regard Mr. Sandi stated that he was ready and would discuss it beforehand at the routine quarterly meeting of the board. ${ }^{32}$

\section{E. Conclusion}

Based on the discussion that has been done, then the conclusions can be formulated as follows: Response of the mosque management and or foundation, one mosque, namely Babussalam Mosque in East Lampung Pekalongan objected if it was built in the front yard of shops or productively managed. As for the reason, it was discussed and the majority of worshipers disagreed. In addition, the yard is not too broad, so it is used for parking vehicles. One mosque agreed to conduct a mosque-based productive waqf management, by building shops in its front yard. But for

30 Nanang Setiawan, Wawancara Dengan Sekretaris Yayasan Masjid AlMuhajirin Abung Semuli Lampung Utara.

31 Sandi, Wawancara Dengan Ketua Ta'mir Masjid Al-Muhajirin Abung Semuli Lampung Utara, 10 September 2018.

32 Sandi. 
now it might not be possible, considering the mosque renovations will be carried out. Two mosques, the Taqwa Punggur Mosque and Al-Muhajirin Mosque Abung Semuli North Lampung, all the officials who were used as informants agreed and strongly agreed to the management of the mosquebased productive waqf, by building shops in its front yard. The management of these two mosques said they were ready to follow up and realize the next steps to make this happen[.]

\section{REFERENCES}

Abdul Aziz. Wawancara Dengan Ketua Ta'mir Masjid Taqwa Punggur Lampung Tengah, Agustus 2018.

Ahmad Jazuli. Wawancara Dengan Ketua Yayasan Masjid Al-Muhajirin Abung Semuli Lampung Utara, 9 September 2018.

Amat. Wawancara Dengan Pengurus Masjid Babussalam Pekalongan Lampung Timur, 9 Juli 2018.

Anwar Pitchaya, Ahamed Kameel Mydin Meerab, Muhammad Yusuf Saleemc. "Priority Of Waqf Development Among Malaysian Cash Waqf Donors: An Ahp Approach." Iium Institute Of Islamic Banking And Finance, Journal Of Islamic Finance, 3, No. 1 (2014).

Asngari. Wawancara Dengan Wakil Ketua Masjid Taqwa Punggur Lampung Tengah, Agustus 2018.

“Desa Semuli Jaya, Semuli Raya Merupakan Pemukiman Tentara Nasional Indonesia (Tni) Angkatan Udara Republik Indonesia. Sehingga Tanah Yang Dibangun Di Atasnya Masjid Al-Muhajirin Merupakan Tanah Milik Auri Yang Telah Diwakafkan Untuk Masjid.," T.T.

Direktorat Pemberdayaan Wakaf Dirjend Bimbingan Masyarakat Islam Departemen Agama. Model Pengembangan Wakaf Produktif. Jakarta: Deoartemen Agama Ri., 2008.

Imam Syafi'i. Wawancara Dengan Dewan Pembina Masjid Jami' Batanghari Lampung Timur, 4 Juli 2018.

Karyoso. Wawancara Dengan Ketua Masjid Jami' Batanghari, 4 Juli 2018.

Mu'allim, Amir. "Pengaruh Pengelolaan Wakaf Di Mesir Terhadap Pengelolaan Harta Wakaf Pendidikan Di Indonesia." Jurnak Akademika 20, No. 01 (2015).

Muhyar Fanani. Berwakaf Tak Harus Kaya: Dinamika Pengelolaan Wakaf Uang Di Indonesia. Walisongo Press, 2010.

Munir, Akhmad Sirojudin. "Optimalisasi Pemberdayaan Wakaf Secara Produktif." Jurnal Ummul Qura Vi, No. 2 (September 2015)

Nanang Setiawan. Wawancara Dengan Sekretaris Yayasan Masjid AlMuhajirin Abung Semuli Lampung Utara, 9 September 2018. 
"Observasi Sekitar Masjid Al-Muhajirin Abung Semuli Lampung Utara," 9 September 2018.

"Observasi Sekitar Masjid Babussalam Pekalongan Lampung Timur," 7 Juli 2018.

“Observasi Sekitar Masjid Taqwa Punggur Lampung Tengah," Agustus 2018.

Panduan Pemberdayaan Tanah Wakaf Produktif Strategis Di Indonesia, T.T.

Romi. Wawancara Dengan Ketua Masjid Babussalam Pekalongan Lampung Timur, 8 Juli 2018.

Sandi. Wawancara Dengan Ketua Ta'mir Masjid Al-Muhajirin Abung Semuli Lampung Utara, 10 September 2018.

"Sebelumnya Menyatu Dengan Kecamatan Abung Selatan, Kemudian Dilakukan Pemecahan, Sehingga Abung Semuli Menjadi Kecamatan Sendiri.," T.T.

Suhairi. "Implementasi Fungsi-Fungsi Manajemen Dalam Pengelolaan Wakaf Produktif Di Singapura." Jurnal Akademika, 20, No. 01 (Juni 2015).

Supri. Wawancara Dengan Sekretaris Ta'mir Masjid Babussalam Pekalongan Lampung Timur, 9 Juli 2018.

Syafii Antonio. "Pengantar Pengelolaan Wakaf Secara Produktif, Dalam Buku Yang Ditulis Oleh Achmad Djunaidi Dan Thabib Al-Asyhar." Dalam Menuju Era Wakaf Produktif: Sebuah Upaya Progresif Untuk Kesejahteraan Umat. Jakarta: Mitra Abadi Press, 2006.

Undang-Undang Nomor 41 Tahun 2004 Tentang Wakaf (T.T.).

Yolanda, Nursyifa. "Peranan Wakaf Produktif Terhadap Keberlangsungan Usaha Mikro Kecil Menengah (Umkm) Dan Kesinambungan Badan Wakaf Walisongo," T.T., 11. 
390 | AKADEMIKA: Jurnal Pemikiran Islam

Vol. 24, No. 02 July - December 2019 